\title{
Entomofauna diversity in areas of Caatinga under forest management in the semi-arid region of Ceará
}

Lilianne dos Santos Maia, Maria Dalila Martins Leão, Marianne Gonçalves Barbosa, Suyanne Araújo de Souza, Cristiane Ramos Coutinho*, Patrik Luiz Pastori

\begin{abstract}
The Caatinga is characterised by deciduous plant species. The practice in this ecosystem is the production of firewood which, when carried out with no technical criteria, contributes to a reduction in the biodiversity and degradation of the biome. Forest Management Planning has been approved by the Ministry of the Environment; a lower impact on the environment is expected, as there is still little information on the effect on biodiversity. The aim of this study was to evaluate the diversity of soil fauna in areas that adopt a Forest Management Plan. Five areas were selected that adopt Forest Management Planning: Area T1, unexploited for six months; Area T2, unexploited for 2-3 years; Area T3 unexploited for 5-6 years; Area T4, unexploited for 1011 years; and the Control Area (unexploited). Four pitfall traps were installed in each area. The Shannon-Weaver (H') Index, the Pielou Uniformity Index (e) and the Species Richness Index were calculated for the purpose of estimating the existing biodiversity. Total richness varied from 7 to 14 groups for the different collection periods and between the treatments; the highest value for the Shannon Index (0.72) was found during the dry/rainy transition period in the area that had been exploited 5-6 years earlier. The number of specimens is influenced by the various stages of wood exploitation.
\end{abstract}

Keywords: soil arthropods, cutting wood, ecological indexes

\section{Introduction}

The Caatinga biome, characterised by areas of seasonally dry forest, is unique to Brazil. (Pinheiro et al., 2013; Beuchle et al., 2015). The Caatinga has been greatly altered by the practice of cutting firewood, by agriculture, burning, hunting and the continuous movement of cattle and sheep herds, leaving few areas with primary vegetation (Araújo et al., 2010; IBGE 2018). The frequent cutting of the vegetation to be used for timber and firewood, with these exploited areas then being abandoned, results in an imbalance in the ecosystem and a possible loss of biodiversity (Thomaz et al., 2009).

For managed forests, the challenge is to maintain productivity without affecting biodiversity. A detailed knowledge of the ecosystem is therefore necessary, characterising the level of use and manipulation of the environment, so that it does not lose its capacity to recover after interventions have taken place (Avila et al., 2015). Consequently, starting in 2012, several projects have been financed by the Ministry of the Environment for the purpose of guaranteeing the sustainability of native species, and as a result, Management Plans for both timber and non-timber forests that could lawfully meet the energy productivity of the gypsum and ceramics industries, began to assist in balancing exploitation of the semi-arid region (Ministry of the 
Environment, 2012).

Research into forest management planning (FMP) and forestry support the development of the regional forestry sector, contributing to the sustainable exploitation of natural forests by reducing impacts on the environment (Schmidt \& Chichorro, 1990). In FMP, it is essential to have knowledge of the availability of the reserves available for exploitation, correlating this with estimates of the biomass or the diversity of existing species and their potential uses (Meunier et al., 2015).

Soil fauna is linked to the processes of nutrient cycling acting on the decomposition mechanisms of both the litter and soil (Machado et al., 2015). Its distribution is affected by the changes that occur within an ecosystem, especially in areas where the seasonality (hot and rainy seasons) is well defined (Lavelle, 1983; Araújo et al., 2010).

Soil invertebrates therefore have the capacity to change the biological, physical and chemical characteristics of the soil in such a way that the macrofauna can act directly in the interactions that occur during these processes, and is identified by researchers as an indicator of soil quality (Silva et al., 2013; Araújo et al., 2010). Although it plays a fundamental role in an ecosystem, the soil biota has hardly been investigated in some neotropical ecosystems, such as the Caatinga and the Atlantic Forest (Silva et al., 1999; Souto et al., 2008; Araújo et al., 2010). Hence the importance of understanding edaphic organisms, of characterising them and quantifying their abundance.

In view of the above, the aim of this study was to carry out a survey of the diversity of soil arthropods in areas on the Fazenda Alvorada Farm where a forest management plan has been adopted.

\section{Material and Methods}

The research was carried out on the Fazenda Alvorada, a farm located in the town of Croatá, in the district of São Gonçalo do Amarante, in the State of Ceará, Brazil. The farm is located between the BR 222 and CE 341 Highways, at $3^{\circ} 36^{\prime} 26^{\prime \prime} S$ and $38^{\circ} 58^{\prime} 06^{\prime \prime} \mathrm{W}$, at an altitude of $15.92 \mathrm{~m}$. The soil is classified as a
Red-Yellow Argisol (Embrapa, 2018). The mean annual temperature varies from 25 to $30^{\circ} \mathrm{C}$, while the average rainfall is $1,200 \mathrm{~mm}$ per year, with a rainy season from January to May and a dry season from June to December (Ipece, 2007). The climate is considered tropical dry equatorial, very hot and semi-arid, type BSwh' according to the Köppen Geiger classification (Peel et al., 2007).

Areas where a Forest Management Plan (IBP 1214/95) has been adopted were selected, with a rotating exploitation cycle of ten (10) full years. Regions of rotating exploitation in succession were defined within the areas, represented by the following treatments: T1- Area unexploited for six months; T2 - Area unexploited for 2-3 years; T3 - Area unexploited for 5-6 years; T4 - Area unexploited for 10-11 years; and the Control, represented by an area of legal reserve (unexploited).

The soil fauna was collected over 12 months in four different periods, starting in April/ May 2014 (rainy period) and continuing in the rainy/dry transition period (July/August 2014), the dry period (October/November 2014), and ending with the dry/rainy transition period (January/ February 2015). The edaphic fauna was captured using interception (pitfall) traps.

Four traps were placed $10 \mathrm{~m}$ apart in each of the exploited areas. The traps were activated during each of the four periods of the year, i.e. a preservative solution was added to each trap, so that they were ready for capturing the fauna. Seven days after activation, the contents of the traps were removed, placed in plastic bottles, labelled, identified and taken to the Laboratory of Applied Entomology (LEA), located in the Department of Phytotechnology of the Federal University of Ceará, where the contents were washed in running water using $0.10 \mathrm{~mm}$ sieves to remove impurities and the preservative solution, and then stored for sorting in new $50 \mathrm{ml}$ plastic pots containing $70 \%$ alcohol. The captured individuals were sorted with the aid of a stereoscopic binocular microscope (magnifying) and identified at the level of the major groups (Class, Order, Family and/or morphospecies). A more-detailed identification of the taxa was carried out with the assistance of 
specialists from the Federal University of Paraná (UFPR) and also based on specialised literature.

The experimental design was completely randomised with four replications, each replication represented by one trap arranged in each treatments $\mathrm{Tl}$ (unexploited for six months); T2 (unexploited for 2-3 years); T3 (unexploited for 5-6 years); T4 (unexploited for 10-11 years) and the Control (Legal Reserve - unexplored). The data were tabulated in Microsoft Exce ${ }^{\mathrm{TM}}$ spreadsheets (Office, 2010) and evaluated using the DivEs - Diversity of Species v3.0 software, to verify species richness and the Shannon diversity and Pielou uniformity indices, as described below:

First-order Jackknife Species Richness. From this parameter it is possible to presume the richness of individuals present in a community. Studies suggest that this is a good species evaluator. It is calculated by:

$$
E_{D}=S_{\text {obs }}+S 1(f-1 / f)
$$

where: Sobs $=$ number of observed species; $\mathbf{S 1}=$ the number of species present in only one cluster (single-cluster species); and $f=$ the number of clusters containing the nth species of a cluster.

Shannon Diversity Index (H'). This determines the distribution of the number of organisms and the richness of the groups by means of information theory, helping to compress the degree of uncertainty in inferring which species belongs to a population if removed randomly (Ludwig \& Reynolds, 1988), so that the higher the value of $\mathrm{H}^{\prime}$, the greater the diversity of the fauna found in the study area. This index is calculated using the formula:

$$
H^{\prime}=-\sum p_{i} \log p_{i}
$$

where $\mathrm{pi}=$ is the proportion of the species in relation to the total number of specimens found in the surveys.

Pielou Uniformity Index. By means of this index the uniformity of the individuals can be calculated, i.e. it indicates whether the species are evenly distributed. Its value ranges from 0 (minimum uniformity) to 1 (maximum uniformity) and is calculated using the formula:

$(e)=H^{\prime} / \log S$

where: $\mathrm{H}^{\prime}=$ Shannon Index and $\mathrm{S}=$ Total number of groups in the community (Pielou, 1977).

\section{Results}

The groups of captured individuals were classified in the following taxonomic levels: Diplopoda (class); Acari (Subclass); Araneae, Blattodea, Coleoptera, Collembola, Diptera, Hemiptera, Hymenoptera, Isoptera, Orthoptera, Pseudoscorpiones, Scorpiones, Solifugae (order); Formicidae (family) and the larvae of Coleoptera, Diptera and Lepidoptera (morphospecies). Species richness varied from 7 to 14 groups for the different stages of succession (Treatments) and collection periods (rainy, rainy/dry transition, dry and dry/rainy transition) (Table 1).

When comparing the area which had not been exploitated for six months (T1) with the other treatments T2 (2-3 years), T3 (5-6 years), T4 (10-11 years) with no exploitation and with the control (Tc - unexploited), it was found that there was a reduction in species richness in 11 during the dry season, with higher values for richness during the dry/rainy transition period, and equal values for richness for the T3 and T4 treatments during the dry and rainy periods respectively (Table 1). When the different collection periods were compared (rainy period, rainy/dry transition, dry and dry/rainy transition), it was found that for treatments (T1, T2 and T3), values for richness were higher during the rainy period and dry/ rainy transition, and for T4 and TC, during the rainy period and rainy/dry transition (Table 1).

In a general analysis of the diversity indices of Shannon and Pielou, it was found that both indices were lower in the area which had not been exploited for 10-11 years (T4) in the collection carried out during the rainy season. While the highest values for the Shannon index occurred in the area which had been fallow for 5-6 years (T3) during the dry/rainy transition period (Table 1). Similar values were obtained for the Pielou index (0.65) in both T3 and T2 (area with no exploitation for 2-3 years) during the dry period and dry/rainy transition respectively (Table 1).

It was found that the Shannon and Pielou indices had higher values in the Tc area (unexploited), when compared to the values in T1 (area unexploited for six months) (Table 1). In relation to the other areas of succession, it was found that there was an increase in both the Shannon index and the Pielou index in the 
area which had not been exploited for 5-6 years (T3) in relation to the area which had not been exploited for 2-3 years (T2) for all collections, except during the dry period, when the highest values were recorded in T2 (Table 1).

During the rainy/dry transition period, the best indices (Shannon and Pielou) were seen in the area of no exploitation (TC) when compared to the other treatments; whereas, during the dry/ rainy transition period, Tc presented lower indices than the T4 and T3 treatments, the latter being superior to all of the other treatments (Table 1). During the dry season, it was found that the lowest recorded index occurred in $\mathrm{T} 1$ when compared to the other treatments (Table 1).

Table 1. Total richness and ecological indices of the soil entomofauna in areas managed under a forest management plan in different stages of recovery after logging, during four periods of the year (Rainy - April/May 2014, Rainy/ Dry - July/August 2014, Dry - October/November 2014 and Dry/Rainy - January/February 2015), Fazenda Alvorada, São Gonçalo do Amarante, Ceará.

\begin{tabular}{|c|c|c|c|c|c|}
\hline \multirow[t]{2}{*}{ Value } & \multicolumn{5}{|c|}{ Collection Period } \\
\hline & \multirow[t]{2}{*}{ Rainy } & \multicolumn{2}{|c|}{ Rainy/Dry } & \multirow{2}{*}{$\begin{array}{l}\text { Dry } \\
\text { a exploited s }\end{array}$} & Dry/Rainy \\
\hline & & \multicolumn{3}{|c|}{ Treatment 1 - Area exploited six months ago } & \\
\hline Species Richness & & 13.0 & 7.0 & 10.0 & 14.0 \\
\hline Shannon Index & & 0.24 & 0.23 & 0.31 & 0.49 \\
\hline \multirow[t]{2}{*}{ Pielou Index } & & 0.22 & 0.28 & 0.31 & 0.42 \\
\hline & & \multicolumn{4}{|c|}{ Treatment 2 - Area exploited 2-3 years ago } \\
\hline Species Richness & & 12.0 & 7.0 & 9.0 & 12.0 \\
\hline Shannon Index & & 0.44 & 0.14 & 0.62 & 0.46 \\
\hline \multirow[t]{2}{*}{ Pielou Index } & & 0.41 & 0.17 & 0.65 & 0.43 \\
\hline & \multicolumn{5}{|c|}{ Treatment 3 - Area exploited 5-6 years ago } \\
\hline Species Richness & & 12.0 & 11.0 & 10.0 & 13.0 \\
\hline Shannon Index & & 0.51 & 0.45 & 0.50 & 0.72 \\
\hline \multirow[t]{2}{*}{ Pielou Index } & & 0.47 & 0.43 & 0.50 & 0.65 \\
\hline & & \multicolumn{4}{|c|}{ Treatment 4 - Area exploited 10-11 years ago } \\
\hline Species Richness & & 13.0 & 14.0 & 9.0 & 10.0 \\
\hline Shannon Index & & 0.12 & 0.52 & 0.42 & 0.60 \\
\hline \multirow[t]{2}{*}{ Pielou Index } & & 0.11 & 0.45 & 0.44 & 0.60 \\
\hline & & \multicolumn{4}{|c|}{ Control - Area of legal reserve (unexploited) } \\
\hline Species Richness & & 12.0 & 10.0 & 9.0 & 9.0 \\
\hline Shannon Index & & 0.25 & 0.59 & 0.41 & 0.51 \\
\hline Pielou Index & & 0.23 & 0.59 & 0.43 & 0.53 \\
\hline
\end{tabular}

From the results, it was seen that individuals belonging to the orders Acari, Collembola and Diptera and to family Formicidae were the most frequent in each of the different periods of succession (Table 2 and 3), with reductions in the number of individuals from the orders Acari and Diptera during the rainy/dry transition and dry period, and Collembola during the rainy/dry transition (Table 3).

The order Solifugae was found in the area where wood had been cut six months (T1) earlier, for collections made during the dry season (Table 3) and the start of the first rains (Table 2). The greatest occurrence of family Formicidae occurred for all periods of succession during the rainy/dry transition compared to the other collection periods (Table 3). The orders Acari and Collembola were more expressive in T4 (rainy period) and $\mathrm{T} 1$ (dry/rainy transition) (Table 2). Other, more expressive collections were found, e.g. Acari (T4, rainy) and Collembola (T1, dry/rainy).

Individuals belonging to the order Pseudoscorpiones were recorded in greater quantities in the unexploited area (Control) when compared to the other treatments; an exception occurred in the newly exploited area (T1), which in the collection during the dry/rainy transition period presented more organisms of this order (Table 2). Isoptera occurred more frequently during three periods of succession: the area unexploited for 5-6 years (T3), the area unexploited for 10-11 years (T4) and the area unexploited for six months (T1), during the dry period, rainy/dry transition, and dry/rainy transition respectively (Table 2 and 3 ). 
Table 2. Abundance of soil arthropods (sum of all the traps) by taxonomic group, during the dry/rainy transition and rainy periods, in areas of Caatinga under forest management, Fazenda Alvorada, São Gonçalo do Amarante, Ceará.

\begin{tabular}{|c|c|c|c|c|c|c|c|c|c|c|c|c|c|}
\hline \multirow{2}{*}{\multicolumn{4}{|c|}{ Taxonomic Group }} & \multicolumn{10}{|c|}{ Collection Period } \\
\hline & & & & \multicolumn{5}{|c|}{ Dry/Rainy } & \multicolumn{5}{|c|}{ Rainy } \\
\hline Class & Order & Family & Morfospecies & T1 & T2 & T3 & T4 & Tc & T1 & T2 & T3 & T4 & Tc \\
\hline \multicolumn{4}{|l|}{ Diplopoda } & 2 & 4 & 1 & 1 & 1 & 0 & 0 & 0 & 0 & 1 \\
\hline \multirow[t]{5}{*}{ Aracnida } & Araneae & & & 27 & 18 & 111 & 13 & 26 & 26 & 15 & 41 & 16 & 22 \\
\hline & Acari & & & 2669 & 1419 & 606 & 400 & 422 & 5569 & 2470 & 1438 & 13737 & 7465 \\
\hline & Scorpiones & & & 2 & 0 & 3 & 0 & 0 & 0 & 0 & 0 & 0 & 0 \\
\hline & Pseudoscorpione & & & 13 & 5 & 10 & 6 & 4 & 4 & 1 & 3 & 5 & 12 \\
\hline & Solifugae & & & 1 & 0 & 0 & 0 & 0 & 0 & 0 & 0 & 0 & 0 \\
\hline \multirow[t]{12}{*}{ Insecta } & Collembola, & & & 1417 & 1331 & 589 & 742 & 1275 & 366 & 641 & 2245 & 325 & 1079 \\
\hline & Orthoptera & & & 18 & 12 & 17 & 11 & 29 & 15 & 6 & 4 & 3 & 9 \\
\hline & Isoptera & & & 21 & 9 & 1 & 0 & 0 & 0 & 0 & 0 & 0 & 0 \\
\hline & Blattodea & & & 0 & 0 & 1 & 0 & 0 & 0 & 0 & 0 & 2 & 0 \\
\hline & Hemiptera & & & 11 & 1 & 5 & 1 & 0 & 12 & 7 & 52 & 9 & 10 \\
\hline & Coleoptera & & & 22 & 10 & 56 & 26 & 39 & 29 & 15 & 26 & 59 & 25 \\
\hline & Hymenoptera & & & 10 & 11 & 19 & 4 & 13 & 15 & 26 & 37 & 40 & 25 \\
\hline & & Formicidae & & 121 & 117 & 291 & 111 & 104 & 90 & 336 & 205 & 160 & 127 \\
\hline & Diptera & & & 331 & 81 & 183 & 304 & 118 & 182 & 105 & 130 & 95 & 65 \\
\hline & & & $\begin{array}{l}\text { Coleoptera } \\
\text { Larvae }\end{array}$ & 0 & 0 & 0 & 0 & 0 & 6 & 6 & 2 & 11 & 11 \\
\hline & & & $\begin{array}{l}\text { Lepidoptera } \\
\text { Larvae }\end{array}$ & 2 & 0 & 0 & 0 & 0 & 5 & 0 & 1 & 0 & 2 \\
\hline & & & $\begin{array}{l}\text { Diptera } \\
\text { Larvae }\end{array}$ & 0 & 0 & 0 & 0 & 0 & 9 & 2 & 13 & 13 & 0 \\
\hline
\end{tabular}

$\mathrm{Tl}$ = Area exploited around 6 months ago; T2 = Area exploited around 2-3 years ago; T3 = Area exploited around 5-6 years ago; T4: Area exploited around 11 years ago, and Tc $=$ Control - area of legal reserve (unexploited).

Table 3. Abundance of soil arthropods (sum of all the traps) by taxonomic group, during rainy/dry transition and dry periods in areas of Caatinga under forest management, Fazenda Alvorada, São Gonçalo do Amarante, Ceará.

\begin{tabular}{|c|c|c|c|c|c|c|c|c|c|c|c|c|c|}
\hline \multirow{2}{*}{\multicolumn{4}{|c|}{ Taxonomic Group }} & \multicolumn{10}{|c|}{ Collection Period } \\
\hline & & & & \multicolumn{5}{|c|}{ Rainy/Dry } & \multicolumn{5}{|c|}{ Dry } \\
\hline Class & Order & Family & Morfospecies & $\mathrm{T} 1$ & T2 & T3 & T4 & Tc & $\mathrm{T1}$ & T2 & T3 & T4 & Tc \\
\hline \multicolumn{4}{|l|}{ Diplopoda } & 0 & 0 & 0 & 0 & 0 & 0 & 0 & 0 & 0 & 0 \\
\hline \multirow[t]{5}{*}{ Aracnida } & Araneae & & & 27 & 26 & 51 & 29 & 53 & 10 & 41 & 7 & 26 & 22 \\
\hline & Acari & & & 13 & 14 & 18 & 103 & 9 & 12 & 7 & 0 & 9 & 5 \\
\hline & Scorpiones & & & 1 & 0 & 1 & 3 & 0 & 2 & 3 & 0 & 1 & 0 \\
\hline & Pseudoscorpione & & & 0 & 0 & 2 & 14 & 25 & 1 & 8 & 1 & 1 & 8 \\
\hline & Solifugae & & & 0 & 0 & 0 & 0 & 0 & 11 & 0 & 0 & 0 & 0 \\
\hline \multirow[t]{13}{*}{ Insecta } & Collembola, & & & 0 & 10 & 17 & 40 & 46 & 681 & 59 & 43 & 138 & 86 \\
\hline & Orthoptera & & & 3 & 17 & 16 & 12 & 119 & 2 & 3 & 4 & 4 & 2 \\
\hline & Isoptera & & & 0 & 0 & 0 & 35 & 0 & 0 & 1 & 247 & 0 & 0 \\
\hline & Blattodea & & & 2 & 1 & 25 & 48 & 7 & 0 & 0 & 0 & 0 & 0 \\
\hline & Hemiptera & & & 0 & 0 & 1 & 3 & 0 & 1 & 0 & 0 & 0 & 0 \\
\hline & Coleoptera & & & 5 & 2 & 12 & 48 & 32 & 3 & 3 & 3 & 5 & 6 \\
\hline & Hymenoptera & & & 0 & 0 & 0 & 1 & 0 & 0 & 0 & 4 & 0 & 0 \\
\hline & \multicolumn{3}{|c|}{ Formicidae } & 461 & 1026 & 444 & 815 & 562 & 139 & 103 & 87 & 361 & 332 \\
\hline & Diptera & & & 14 & 1 & 6 & 3 & 51 & 0 & 0 & 4 & 3 & 3 \\
\hline & & & $\begin{array}{l}\text { Coleoptera } \\
\text { Larvae }\end{array}$ & 0 & 0 & 0 & 1 & 1 & 0 & 0 & 2 & 0 & 1 \\
\hline & & & $\begin{array}{l}\text { Lepidoptera } \\
\text { Larvae }\end{array}$ & 0 & 0 & 0 & 1 & 0 & 0 & 0 & 0 & 0 & 0 \\
\hline & & & $\begin{array}{l}\text { Diptera } \\
\text { Larvae } \\
\end{array}$ & 0 & 0 & 0 & 0 & 0 & 0 & 0 & 0 & 0 & 0 \\
\hline & \multicolumn{3}{|c|}{ Total } & 526 & 1097 & 593 & 1156 & 905 & 862 & 228 & 402 & 548 & 465 \\
\hline
\end{tabular}


Individuals belonging to the order Coleoptera showed greater activity in T4 (an area, fallow for 10-11 years), during the initial collections (rainy period and rainy/dry transition) (Table 2 and 3). In contrast, there was a reduction in the number of these organisms captured in all treatments during the dry season (Table 3). Comparing the dry periods and the dry/rainy transition (Table 2 and 3), an increase was seen in the number of individuals of Coleoptera, Orthoptera and Hymenoptera in all treatments.

The orders Aranae, Coleoptera and Orthoptera were not the most expressive for number of individuals, but stood out, as they were present in each treatment (different areas of succession) and collection period (Table 2 and 3). When the different collection periods were analysed, it was found that in general the groups of larvae (Diptera, Coleoptera and Lepidoptera) did not achieve a high level of expression, the greatest occurrence occurring during the rainy season (Table 2). This also occurred with the class Diplopoda and the Blattodea group, with the greatest presence during the dry/rainy transition (Table 2) and the rainy/dry transition (Table 3) respectively.

The presence of Scorpiones was not seen during the rainy season (table 2), and their occurrence during the other collection periods was low (Table 2 and 3 ). The hemiptera group was more expressive during periods with rain (rainy, rainy/dry transition) (Table 2), with a reduction in the number of individuals during the dry periods (dry and rainy/dry transition) (Table 3).

\section{Discussion}

The vegetation that remains on the ground, together with its composition and amount of litter deposition, are factors that can influence both the diversity and richness of soil arthropods (Machado et al., 2015). The greatest richness recorded in the newly exploited area (T1) during the rainy and dry periods and the rainy/ dry transition was possibly due to the amount of plant material deposited on the ground, since it is common to find plant remains after removing the wood (firewood production), when the occurrence of groups that have a detritivorous feeding habit (Coleoptera, Collembola, Ants and Termites) is to be expected.

The greatest values for richness found in the area with no exploitation for 5-6 years (T3) during the rainy and rainy/dry collection periods and during the dry period and the dry/ rainy transition, can be explained by the amount of decomposed plant material that may have provided survival conditions to the edaphic organisms, thereby allowing more variability. The greater availability of resources in secondary forests during the dry season stimulates biological activity, and is one factor that favours the vertical migration of individuals from the soil to the litter, promoting an abundance of soil fauna (Cunha Neto et al., 2012).

The increase in richness in T4 (area unexploited for 10-11 years) for the collections carried out during the rainy period and rainy/dry transition, may be associated with two factors. One, because the area had been fallow for so long, showing similar conditions to those of the Control (unexploited); long fallow periods tend to favour soil arthropods due to the stability and rebalancing of the ecosystem (Menezes et al., 2009). The second factor may be related to the climate, since the collections were made during the occurrence of rainfall (rainy period and rainy/dry transition). The greater number of soil arthropods during the rainy period can be attributed to the increase in organic matter content during this period, with a greater contribution from the rhizospheric soil due to the more effective presence of the herbaceous stratum (Poggiani et al., 1996).

In natural ecosystems, the rainy period favours the resumption of insect activity, resulting in greater abundance compared to the dry period (Wolda, 1988).

Reduced values for the Shannon index show that there was a dominance of one or more groups (Calvi et al., 2010). When values for the Pielou index are closer to one, they indicate greater group evenness, i.e. groups are equally distributed (Abreu et al., 2014). It can therefore be said that the low values for the Shannon and Pielou indices found in the area that had been fallow for 10-11 years (during the rainy season) is associated with the dominance of the Acari group over the other groups. The results obtained 
in the present study agree with those of Resende et al. (2013), who attributed this fact to the parthenogenesis practised by some species of Acari favouring a rapid increase in population. In an experiment in grass-covered areas in rural and urban zones, the Acari group was found to be the second largest in number of captured individuals, noting that their presence occurred because they were free-living and abundant in the soil, in the humus and especially in the plants (Araújo et al., 2010).

The fallow period of approximately 5-6 years together with the dry/rainy transition period, favoured the greatest group diversity recorded in the present study, reflecting in higher values for the Shannon and Pielou indices. As this is an area where no wood has been removed for 5-6 years, it can be inferred that the amount of decomposed plant material was sufficient to allow favourable conditions for the development of edaphic organisms, thereby affording greater variability. These results were similar to those found by Machado et al. (2015), where the greater activity of some groups was seen in a secondary forest of advanced stage, which automatically reflects in greater values for the Shannon and Pielou indices. They attributed this fact to the successional process of the forest on the composition of the entomofauna. The amount of biomass supplied by the plants contributes to a greater availability of resources, which favours the arthropods present in the soil (Cunha Neto et al., 2012).

The large number of individuals of the orders Acari, Collembola and Diptera and the family Formicidae, in comparison to the other groups collected during each period and stage of succession, was also found in other studies (Souto et al., 2008; Calvi et al., 2010; Benazzi et al., 2013; Abreu et al., 2014). Some individuals of Formicidae are litter fragmenters, and are mainly seen in areas of secondary forest (Calvi et al., 2010). Therefore, areas with fallow periods of greater than 5-6 years can be classified as secondary forests by the amount of plant material. The presence of Formicidae in the recently exploited area (T1) during the dry period is similar to that of sugarcane when submitted to burning, as reported by Benazzi et al. (2013), since, in both areas there is considerable solar incidence, meaning that the Formicidae found under such conditions are from species capable of colonising environments submitted to a high incidence of light and heat.

The reduction in the number of individuals from the orders Acari and Collembola which was seen in collections during the rainy/dry transition and the dry period is linked to climate factors, especially humidity, as this is a period of reduced or practically no rainfall. Specimens of Acari and Collembola were reported with greater frequency during the dry/rainy and rainy periods, irrespective of the amount of straw present in each treatment. The greater number of specimens from these two groups was therefore attributed to the ease of movement and adaptation of these groups to humid environments (Abreu et al., 2014).

The greater frequency of Diptera recorded in the present study may be related to the great diversity of the order, which inhabits the most diverse environments, and to its food habit, from haematophagous species to predators of other arthropods (Copatti \& Daudt, 2009; Abreu et al., 2014), also to the presence of a rainy period that favours the resumption of insect activity and to the increase in organic matter content that takes place during that period (Poggiani et al., 1996; Wolda, 1988). The results obtained in the present study were similar to those in studies carried out by Calvin et al. (2010), where the largest number of Diptera was recorded in areas of old secondary forest, and can be explained by the fact that this Order uses the soil as a temporary shelter.

Individuals of Solifugae found during the dry period and the dry/rainy transition in the area exploited around six months earlier (T1), have been little studied due to the obstacles encountered in observing these organisms in the forest, together with the low numbers caught in collections (Meijden, 2012). Most of the reported Solifugae species inhabit areas of desert or of Mediterranean climate, and are considered important predators in arid environments with scarce vegetation (Conrad \& Cushing, 2011; Karatas \& Ucak, 2013). The presence of Solifugae can therefore be attributed to the small amounts 
of biomass, since they were found in the recently cut area and with no precipitation (Dry period) and/or little precipitation /dry/rainy transition period). Some species have even been reported in areas of soil with high concentrations of salt and sulphur (Karatas \& Ucak, 2013), so the occurrence of individuals of this group in the area under study deserves further research.

The greatest occurrence of Isoptera in the area which had not been exploited for 5-6 years (during the dry season) can be attributed to the plant remains that make up the litter being used as a food source by these organisms. This result agrees with the data obtained by Moço et al. (2005) in studies carried out in areas of eucalyptus, unpreserved forest, preserved forest, poultry farming and pasture, who recorded a higher occurrence of this order during the dry period, explaining this fact by the food habit of the order. In addition, the presence of Isoptera in areas of secondary forest can be attributed to the remains of agricultural or livestock activities, or other activities that allow the insects to feed on the roots of earlier plants (Machado et al., 2015).

Hymenoptera, by virtue of their variety, diversity and functionality, are considered important bioindicators in tropical and subtropical soils, since they are sensitive to disturbances occurring in the soil used by species during the processes of nesting and mating (Rovedder et al., 2009; Tapia et al., 2015). In the present study, the greatest expressiveness of the Hymenoptera group was seen during the dry/rainy and rainy periods in all the treatments. It can be inferred from this that the different fallow periods did not influence these individuals, but rather the climate factors, since there was a reduction in the number of individuals of this order during the rainy/dry transition and the dry period. These results differ from those obtained by Girraca et al. (2003), who found a small amount of Hymenoptera in areas of crop succession but not during periods of drought, attributing this fact to the type of management adopted.

Pseudoescorpiones were expressively recorded in the area of legal reserve (unexploited) during the rainy/dry period. However, it should be pointed out that this group was also found during every collection period, except in the area that had been unexploited for six months (TI), and in the area unexploited for around 2-3 years (T2) during the rainy/dry period, showing an increase in the number of individuals in areas with a longer period of ecological succession. In view of the above, it can be inferred that the period of succession contributes to the recovery of the exploited environment, since the presence of Pseudoescorpiones is indicative of good soil quality, as individuals are usually predators and play a role in regulating the trophic chain (Cunha Neto et al., 2012). Research carried out in areas of preserved forest also showed the presence of this group (Moço et al., 2005), so that it can be concluded that these individuals mainly remain in areas of ecological balance.

The Aranae group was found during each collection period and treatment, which can be attributed to the composition of the plants present in each area. According to Varjão et al. (2010), these organisms use the litter as protection in areas of high temperature. In a study by Benazzi et al. (2013) in areas of raw cane and burned/raw cane, the authors considered the presence of the Aranae group (Predators) as indicative of a stable ecosystem, since these environments offer a great variety of prey, with the obvious presence of a food chain.

The presence of Coleoptera and Orthoptera for each treatment and collection period indicates that there is a great variety of organic material, for example live, dead and decomposing animals, plant material, seedlings and fungi (Araújo et al., 2015). This occurs less during the dry period, since the rainy season favours the hatching and subsequent resumption of insect activity (Poggiani et al., 1996; Wolda, 1988). Coleoptera include a large diversity of cosmopolitan, saprophagous individuals that are resistant to environmental change, play a role in nutrient-cycling and are also used in biological pest-control (Souto et al., 2008; Copatti \& Daudt, 2009). Orthoptera, on the other hand, represent an order of more than 20 thousand catalogued species worldwide, with greater diversity in the tropics; they are considered primary consumers, and both the diversity of the vegetation and the microclimate influence the presence of organisms of this Order (Gonçalves \& Oliveira, 2013). 
The behaviour of the edaphic groups under observation proved to be an indicator source of the ecosystem regeneration process in areas of succession (Treatments), explicit by the presence of edaphic groups (predators and saprophytes) in areas with a longer period of no exploitation, as well as by the high expressiveness of Acari, Collembola, Diptera and Formicidae in each collection period. This result agrees with data obtained by Moço et al. (2005) in studies carried out in areas of eucalyptus, unpreserved forest, preserved forest, poultry farming and pasture, which during the dry period recorded a higher occurrence of this order that could be explained by its food habit.

\section{Conclusion}

The specimens found are influenced by the different stages of wood exploitation, with the visible predominance of such groups as Acari, Collembola, Formicidae and Diptera, and the occurrence of Solifugae during the dry period and dry/rainy transition. The presence of predators (Aranae and Pseudoescorpiones) and decomposers (Coleoptera) indicates an environment in a state of regeneration. The succession of fallow periods contributed to the establishment and restructuring of groups of soil arthropods in the ecosystem under study, demonstrating the viability of a 10-year cycle of wood exploitation.

\section{Acknowledgements}

The authors are grateful to the Conselho Nacional de Desenvolvimento Científico e Tecnológico (CNPq), the Coordenação de Aperfeiçoamento de Pessoal de Nível Superior (CAPES), and the Fundação Cearense de Apoio ao Desenvolvimento Científico e Tecnológico (FUNCAP) for the study scholarships. The authors are also grateful for the support and encouragement of Mauro Ferreira Lima and Grupo Tavares, Ceará, for their logistical support and use of the experimental area.

\section{Referências}

Abreu, R.R.L., Lima, S.S., Oliveira, N.C.R., Leite L.F.C. 2014. Fauna edáfica sob diferentes níveis de palhada em cultivo de cana-de-açúcar. Pesquisa Agropecuária Tropical 44:409-416.
Araújo, A.S.F.D., Eisenhaver, N., Nunes, L.A.P.L., Leite, L.F.C., Cesarz, S. 2015. Soil surfaceactive fauna in degraded and restored lands of Northeast Brazil. Land Degradation e Development 26:1-8.

Araújo, V.F.P., Bandeira, A.G., Vasconcellos, A. 2010. Abundance and stratification of soil macroarthropods in a Caatinga Forest in Northeast Brazil. Brazilian Journal of Biology 70:737-746.

Avila, A.L.D., Ruschel, A.R., Carvalho, J.O.P.D., Mazzei, L., Silva, J.N.M., Lopes, J.D.C., Araujo, C.F.D., Bauhus, J. 2015. Medium-term dynamics of tree species composition in response to silvicultural intervention intensities in a tropical rain Forest. Biological Conservation 191:577-586.

Benazzi, E.S., Bianchi, M.O., Correia, M.E.F., Lima, E., Zonta, E. 2013. Impactos dos métodos de colheita da cana-de-açúcar sobre a macrofauna do solo em área de produção no Espírito Santo - Brasil. Semina: Ciências Agrárias 34:3425-3442.

Beuchle, R., Recchi, R.C., Shimabukuro, Y.E., Seliger, R., Eva, H.D., Sano, E., Achard, F. 2015. Land cover changes in the Brazilian Cerrado and Caatinga biomes from 1990 to 2010 based on a systematic remote sensing sampling approach. Applied Geography 58:1 16-127.

Calvin, G.P., Pereira, M.G., Junior Espíndula, A., Machado, D.L. 2010. Composição da fauna edáfica em duas áreas de floresta em Santa Maria de Jetibá-ES, Brasil. Acta Agronômica 59:37-45.

Conrad, K.R., Cushing, P.E. 2011. Observations on hunting behavior of juvenile Chanbria (Solifugae: Eremobatidae). The Journal of Arachnology 39:183-184.

Copatti, C.E., Daudt, C.R. 2009. Diversidade de artrópodes na serapilheira em fragmentos de mata nativa e Pinus elliottii (Engelm. Var elliottii). Ciência e Natura 31:95-113.

Cunha Neto, F.V., Correia, M.E.F., Pereira, G.H.A., Pereira, M.G., Leles, P.S.S. 2012. Soil fauna as an indicator of soil quality in forest stands, pasture and secondary forest. Revista Brasileira de Ciências do Solo 36:1407-1417.

Empresa Brasileira de Pesquisa Agropecuária (EMBRAPA). 2018. Sistema Brasileiro de Classificação do Solos. Brasília, 4 ed. 356p.

Giracca, E. M. N., Antoniollo, Z. L., Eltz, F. L. F., Benedetti, E., Lasta, E., Venturini, S. F., Venturini, E. F., Benedetti, T. 2003. Levantamento da meso e macrofauna do solo na microbacia do Arroio Lino, Agudo/RS. Revista Brasileira de Agrociência 9:257-261. 
Gonçalves, O.R., Oliveira, C.J. 2013. Análise da fauna de orthoptera associada à decomposição de carcaça de suíno. Revista Eletrônica Novo Enfoque 17:106-110.

Instituto Brasileiro de Geografia e Estatística - IBGE. Biomas continentais do Brasil. https:// concla.ibge.gov.br/images/pdf/vamoscontar/ texto_biomas.pdf. <Acesso em 22 outubro 2018>

Instituto de Pesquisa e estratégia econômica do Ceará - IPECE. Perfil básico municipal, São Gonçalo do Amarante. Fortaleza: SEPLAN Secretaria do Planejamento e Coordenação, Governo do Estado do Ceará, Ceará. 2007 http:// ipece.ce.gov.br/perfil_basico_municipal/.../ Sao\%20Goncalo\%20do\%20Amarant/ <Acesso em 03 abril 2015>

Karataş, A., Uçak, M. 2013. A new Barrussus Roewer, 1928 (Solifugae: Karschiidae) from Southern Turkey. Turkish Journal of Zoology 37:594600.

Lavelle, P. 1983. The soil fauna of tropical savannas. The community structure. In: BOURLIÈRE, F., ed. Tropical savannas 477-484.

Ludwig, J.A., Reynolds, J.F. 1988. Statistical Ecology. A primer on Methods and computing. John Wiley and Sons, New York, USA, 337 p.

Machado, D.L., Pereira, M.G., Correia, M.E.F., Diniz, A.R., Menezes, C.E.G. 2015. Fauna edáfica na dinâmica sucessional da Mata Atlântica em floresta estacional semidecidual na bacia do Rio Paraíba do Sul - RJ. Ciência Florestal 25:91-106.

Meijden, A.V.D., Langer, F., Boistel, R., Vagovic, P., Heethof, M. 2012. Functional morphology and bite performance of raptorial chelicerae of camel spiders (Solifugae). The Journal of Experimental Biology 215:3411-3418.

Menezes, C.E.G., Correia, M.E.F., Pereira, M.G., Batista, I., Rodrigues, K.M., Couto, W., Anjos, L.H.C., Oliveira, I.P. 2009. Macrofauna edáfica em estádios sucessionais de floresta estacional e pastagem mista em Pinheiral (RJ). Revista Brasileira de Ciências do Solo 33:1647-1656.

Meunier, I.M.J., Ferreira, R.L.C., Silva, J.A.A.D. 2015. Curva $A B C$ de estoques de densidade e volume aplicada ao manejo florestal de caatinga. Scientia Agricola 43:477-484.

Ministério do Meio Ambiente. Biomas Caatinga. 2012 . http://www.mma.gov.br/biomas/ caatinga/ <Acesso em 03 abril 2015>

Moço, M.K.S., Gama, E.F.R., Gama, A.C.R., Correia, M.E.F. 2005. Caracterização da fauna edáfica em diferentes coberturas vegetais na região norte Fluminense. Revista Brasileira de Ciências do Solo 29:555-564.
Peel, M.C., Finlayson, B.L., Mcmahon, T.A. 2007. Updated world map of the Köppen-Geiger climate classification. Hydrology and Earth System Sciences 11:1633-1644.

Pielou, E.C. 1977. Mathematical ecology. John Wiley, New York, USA, 385p.

Pinheiro, E.A.R., Costa, C.A.G., Araújo, J.C.D. 2013. Effective root depth of the Caatinga biome. Journal of Arid Environments 89:1-4.

Poggianl, F., Oliveira, R.E. de., Cunha, G.C. da. 1996. Práticas de ecologia florestal. Documentos Florestais, 6:1-44, 1996.

Resende, A.S., Campello, E.F.C., Silva, G.T.A., Rodrigues, K.M., Oliveira, W.R.D., Correia, M.E.F. 2013. Artrópodes do solo durante o processo de decomposição da matéria orgânica. Agronomía Colombiana 31:89-94.

Rovedder, A.P.M., Eltz, F L., Drescher, M.S., Schenato, R.B., Antoniolli, Z.I. 2009. Organismos edáficos como bioindicadores da recuperação de solos degradados por arenização no Bioma Pampa. Ciência Rural 39:1061-1068.

Silva, E.G. \& Bandeira, A.G. 1999. Abundância e distribuição vertical de cupins (Insecta, Isoptera) em solo de Mata Atlântica, João Pessoa, Paraíba. Revista Nordestina de Biologia 13:13-36.

Silva, R.F.D., Corassa, G.M., Bertollo, G.M., Santi, A.L., Steffen, R.B. 2013. Fauna edáfica influenciada pelo uso de culturas e consórcios de cobertura do solo. Pesquisa Agropecuária Tropical 43:130-137.

Souto, P.C., Gama, E.F., Gama, A.C.R., Correia, M.E.F. 2008. Comunidade microbiana e mesofauna edáficas em solo sob caatinga no semi-árido da Paraíba. Revista Brasileira de Ciências do Solo 32:151-160.

Tapia, D.H., Silva, A.X., Ballesteros, G.I., Figueroa, C.C., Niemeyer, H.M., Ramírez, C.C. 2015. Differences in learning and memory of host plant features between specialist and generalist phytophagous insects. Animal Behaviour 106:110.

Thomaz, C., Da Costa, C., De Oliveira, M.A.J., Accioly, L.J.D.O., Da Silva, F.H.B.B. 2009. Análise da degradação da Caatinga no núcleo de desertificação do Seridó (RN/PB). Revista Brasileira de Engenharia Agrícola e Ambiental 13:961-974.

Varjão, S.L.D.S., Benati, K.R., Peres, M.C.L. 2010. Efeitos da variação temporal na estrutura da serrapilheira sobre a abundância de aranhas (Arachnida: Araneae) num fragmento de Mata Atlântica (Salvador, Bahia). Revista Biociências 16:34-45. 
Schmidt, P.B., Chichorro, J.F. 1990. Diagnóstico e avaliação das pesquisas sobre silvicultura e manejo florestal na Amazônia. Cuiabá: UFMT. 79.

Wolda, H. 1988. Insect seasonality:Why? Annual Review of Ecology and Systematics 19: 1-18. 